Milena M. Kaličanin

Univerzitet u Nišu

Filozofski fakultet, Departman za anglistiku

milena.kalicanin@filfak.ni.ac.rs

\section{Kristina M. Petrović}

Univerzitet u Nišu, Filozofski fakultet

Doktorske studije filologije (srbistika)

tinkapetrovic@yahoo.com
Original research paper

UDC: $821.111 .09-2 " 15 / 16 ": 371.3$

DOI: 10.19090/MV.2021.12.133-148

\title{
TEACHING DRAMA: CHALLENGES AND BENEFITS ${ }^{1}$
}

ABSTRACT: It has frequently been stated that the dramatic method of teaching is rather efficient in students' personal development. The basic practical aspect of this teaching method involves the acquisition of various social and language skills which point to its immense interdisciplinary potential. Apart from the benefits, teaching drama represents a highly challenging task for educators since they are supposed to mediate between the world of artists and the recipients of their art. In order to highlight the challenges and benefits of teaching drama, the theoretical framework of the paper relies on the pioneering lecturing work of Heathcote $(1976,1998)$, as well as the critical insights of Freire (2005) and Nussbaum (1997). Their methodical perspectives on drama as a learning medium have been combined with the results of the internal survey the authors of the paper conducted in the period 2016-2018 by teaching Renaissance drama courses at the university level.

Key words: dramatic method of teaching, Heathcote, Freire, Nussbaum, English Renaissance drama.

\section{ПОДУЧАВАЊЕ УЗ ПОМОҺ ДРАМЕ: ИЗАЗОВИ И ПРЕДНОСТИ}

АПСТРАКТ: Често се у академској литератури могу наћи подаци о ефикасности драмског метода подучавања и његовом значају за лични развој студената. Основни практични аспект ове методе наставе обухвата, пре свега, стицање разноврсних друштвених и језичких вештина што указује на њен огроман интердисциплинарни потенцијал. Поред предности, подучавање драме представља изузетно изазован наставнички задатак, јер наставници морају да посредују између света уметника и реципијената њихове уметности. Како би истакли изазове и добре стране подучавања драме, теоријски оквир рада почива на пионирском раду Дороти Хиткот $(1976,1998)$, као и на критичким увидима П. Фреиреа (2005) и М. Нусбаум (1997). Методичке перспективе наведених теоретичара о драми као медијуму учења се у раду комбинују

1 This study was financially supported by the Ministry of Education, Science and Technological Development of the Republic of Serbia. 
са резултатима интерног истраживања спроведеног у периоду од 2016. до 2018. године на Филозофском факултету у Нишу, приликом извођења курса из Енглеске ренесансне драме.

Кључне речи: драмски метод подучавања, Хиткот, Фреире, Нусбаум, енглеска ренесансна драма.

\section{INTRODUCTION}

Although teachers have generally reached a consensus on numerous beneficial aspects of teaching drama, its educational aspects have only recently become a focus of pedagogical interest in Serbia. The issue of methodology and scientific validity of the dramatic method of teaching has been rather ambivalent since the majority of Serbian pedagogues and theoreticians have expressed their concern related to the possible placement of dramatic method of teaching within certain scientific categories. Namely, this method of teaching incorporates the scientific fields of pedagogy and art, but its subject, goals and methods have still remained unspecified and undefined according to strict academia standards. Nonetheless, it has frequently (and rightly!) been stated and proven that the dramatic method of teaching is rather efficient in students' personal development by enabling them to enrich their creative potentials and imaginative faculties.

The basic practical aspect of this teaching method involves the acquisition of various social and language skills which point to its immense interdisciplinary potential. Teaching practices that best describe it involve a theoretical approach to drama and theatre, elocution, dramatization of original texts in class, role-play, theatre forums prepared and conducted by students, students' individual and group performances, applied theatre etc. It goes without saying that a great number of these teaching practices can successfully be applied in class.

Bearing this in mind, we conducted an internal survey at the Faculty of Philosophy in Niš, while teaching the Renaissance drama courses in the period 2016-2018. Our goal was to investigate whether students found the dramatic method of teaching useful, enjoyable and applicable in their future educational development. Apart from the already stated benefits of educational drama, the conducted survey initially shows that the dramatic method of teaching represents a highly challenging task for educators since they are supposed to mediate between the world of artists and the recipients of their art by focusing on (supposedly!) universal themes and sets of values. This is the reason we turned to rather influential methodical perspectives of drama as a learning medium in the pioneering lecturing work of Dorothy Heathcote (discussed in Wagner, 1976 and 
Hornbrook, 1998), as well as the critical insights of Paulo Freire (Pedagogy of the Oppressed, 2005) and Martha Nussbaum (Cultivating Humanity, 1997). Their critical and practical insights enabled us to modernize the prevalent, mostly conservative, teaching methods and, accordingly, innovate and diversify dramatic texts taught in the university curricula. ${ }^{2}$

\section{DRAMATIC METHOD OF TEACHING: EXAMPLES}

\subsection{Dorothy Heathcote}

The greatest revolution in dramatic pedagogy was performed by Dorothy Heathcote (1926-2011), whose lectures were rather inspiring for a vast number of educators that incorporated her methodical principles not only in the domain of teaching drama, but also in teaching literature, history and philosophy in general. Though without formal teaching education, Heathcote was working as a lecturer first at the Durham Institute, and later at the University of Newcastle, which gave her freedom to conduct dramatic workshops in which her students frequently enacted carefully chosen daily life situations. In cooperation with Gavin Bolton, an innovative teaching method was created that marked the English pedagogy of the 1960s and 1970s.

When analyzing their dramatic method of teaching, Hornbrook (1998) describes Heathcote as ,a midwife of creative knowledge” and Bolton as ,a cold evaluator" (Hornbrook 1998: 18). While the conventional approaches to teaching drama were primarily based on ex cathedra lectures, this dramatic method involves the „stand up and show” principle. Imaginative assignments in various social and ethical situations, changes of perspective were mostly included in Heathcote's class that she conducted with students of different age - from the level of primary school to the university level. The main difference from the already existing dramatic workshops in England was Heathcote's idea about the need to improvise. Her students were asked to choose and dramatize a daily life situation that was not a part of any play and, as such, was not already prepared and written for them. The main idea behind this method was for the students to willingly place themselves in certain situations that would potentially be resolved and interpreted based on their

\footnotetext{
2 The mere fact that the University in Novi Sad recognized the significance of dramatic pedagogy as a separate scientific discipline by establishing a special master program dealing predominantly with educational drama and applied theatre (in 2016) testifies to its slow but certain pace of recognition in Serbia.
} 
personal experience. Viewed from this perspective, it becomes quite clear that Heathcote based her model of teaching on (artistic) improvization, students' empathy and acquiring knowledge by merging personal with other people's experience.

One of the benefits of this method of teaching definitely represents the fact that the dramatic dialogue is created during students' performance, which basically means that every student's performance is unique. Hence, these students are able to perceive a clear distinction between the concepts of play and drama: by acting in the play, there is no possibility to personalize the circumstances that are performed; also, being limited by the dramatic text, they are not supposed to express their own reactions to the given situations. On the other hand, drama is based on unpredictable denouements since dramatic conflict is not prepared in advance and is literally based on the opponent's reaction. This is why every performance represents a new challenge for students, because every time they have the possibility to offer different resolutions to a given situation.

This method of teaching is focused on the development of students' intellectual and imaginative capacities and its main goal is to overcome the problem of students' passivity and disinterest in the process of the interpretation of a dramatic text in class. Thus, conflicts during the performance are quite welcome, whereby the emphasis is on the motives, causes and reasons for certain students' choices and not on the actual accomplishment of action.

After the performance, a new drama is created post festum. By using the methods of dialogue and discussion, every new performance brings a possible change in the attitude that inevitably causes different replicas in the same situation enacted. New layers of action, as well as new emotions and viewpoints of actors are unavoidable. Thus, by teaching drama, students are prepared for future personal development not by merely acquiring knowledge but by expanding the boundaries of private experience and perception. This is why Wagner claims that Heathcote's method of teaching mostly and solely revolves around the issues of humanity (1976: 181). Another benefit of this method of teaching that Wagner emphasizes is the fact that dramatic texts are viewed not as fixed and unchangeable categories, but are, quite the opposite, represented in their fluidity - as subjects to constant alterations that enable students to personalize certain unfamiliar dramatic situations (1976: 182).

In Contexts for Active Learning: Four Models to Forge Links Between Schooling and Society (2002), Heathcote explains the main postulates and methods of her dramatic method of teaching. Her teaching practice basically boils down to 
four models: 1. drama used to explore people, 2. mantle of an expert, 3. rolling role, and 4. commission model.

The first model of exploring people is practically based on social collaboration and investigation of the dramatic aspect of the moment students are engaged in. One of three levels of social politics is usually explored: personal psychology, social politics or the question of power. A certain modification of behaviour is needed to make sure that fiction is not intertwined with students' habitual reactions. Invented events are supposed to have a clear focus and productive tension around which drama revolves (usually created by the teacher).

Our practical example of Heathcote's first model of dramatic method of teaching concerned not the actual text of Shakespeare's play Richard III, but the conspicuous structural ambivalence of this English Renaissance's anti-hero. A rather controversial question of Richard III being a hero or a villain was posed to the class, bearing in mind this character's charismatic, almost seductive powers used for making the audience a sort of a willing accomplice in his villainous deeds, but at the same time a long list of the victims that he cruelly executed in order to obtain the English crown was presented. In this way, by expressing disgust or sympathy for Richard, the students were involved in the contemplation of existential questions of a binary opposition of good/evil. All the participants stated their views on this obvious ambivalence and in their performance after a brief discussion in class the roles in Shakespeare's play were slightly modified, whereby the students enacted their own version of the play. They introduced a psychoanalytical approach to Richard's villainy, contemplated the possible causes and symptoms of his villainous behaviour, reconstructed his childhood image, etc. A dominant idea shared by students at the end of this practical task concerned the human capacity for inborn evil. In other words, they posed a question whether Richard was born or made evil. The students' answer to this rather philosophical issue was that he was obviously a victim of social and historical circumstances so that Shakespeare put our whole Western civilization on trial by creating a villain as a perfect mirror image of his society.

Heathcote's second model, the mantle of an expert, is a representation of a social situation in which the teacher has the role of a leader, participant, opponent, organizer and creator of conflict and tension. The teacher's comments and questions enable students to actively engage themselves in a given dramatic situation and take certain roles in the performance on their own. Heathcote recommends the social situations that enable students to be responsible, make their own decisions and accept their consequences. 
Our practical example of Heathcote's second model concerned different aspects of revenge and was based on Shakespeare's play Hamlet. The question was whether the act of revenge could possibly be morally justified. As teachers, we served as the mediators in the creative process, probing the students with the issues of morality, justice, legality, but not offering solutions, which was their way of coping up with the problem as significant members of the society. The general conclusion was that revenge did not represent a socially acceptable mode of behaviour, not only because certain state laws would be broken by harming an individual, but also because one would betray the basic principles of humanity thus reflecting Hamlet's famous moral dilemma: to be or not to be? The students reinforced the idea that if Hamlet actually avenged the death of his father, i.e. murdered the new king then he would have embraced the methods of the society that he rebelled against and ultimately become both its unwilling servant and victim.

Heathcote's rolling role consists of interdisciplinary activities that are incorporated in the dramatic performance. The teacher is supposed to create new projects and give assignments that will enrich the play with new elements. This method represents one of the main components of integrative teaching whose aim is to establish as many interdisciplinary links as possible.

Our practical example in class was based on a totally new project of connecting the chronicles of English historical rulers and Shakespeare's versions of their rule. The students were rather successful in finding similarities and differences between the actual historical and imaginary dramatic characters. For instance, it was rather surprising for the students to discover that historical Richard III was not a detestable figure, that is, not a hunchback with a withered arm as Shakespeare portrayed him. This historical fact made way for further research on this topic, as well as for the reasons Shakespeare created his famous villain as an invalid, with the conspicuous physical deformity. A variety of students' interpretations of this issue just testifies to an important aspect of teaching drama: development of students' critical thinking. According to the students, Shakespeare purposefully created Richard III as a physically deformed creature to reinforce the idea that his physical deformity actually represented a vivid emanation of the deformity of his mind.

Heathcote's commission model implies that the whole project is commissioned by an external investor (imaginary or real) that establishes the deadlines and gives additional motivation to students. Thus it could be a good opportunity to enable students to express their talents - creative writing, singing, 
dancing, acting, that is, developing their creative potentials and imaginative facilities.

These methods are also rather convenient for introducing students to literary works - by enacting a dramatic situation in which students take the roles of protagonists and antagonists, not being informed about the fact that the same topic would be the subject of the literary work they are supposed to read for the class. In this way, their personal attitudes towards certain characters and their problems are created without any external suggestion. Later, this practice enables a debate related to circumstances that cause the unexpected resolution of a given situation social framework, cultural identity, moral customs, etc. By identifying themselves with antagonists and social outcasts, students are taught to develop their critical thinking capacities and simultaneously enhance their imaginative faculties. It goes without saying that they also expand their knowledge about the dominant culture and the possibility to probe into the (im)morality of certain social principles and attitudes usually taken for granted.

\subsection{Paulo Freire}

Apart from Dorothy Heathcote's innovative dramatic method of teaching, the second half of the $20^{\text {th }}$ century is surely marked with a new vision of the educational system whose proponents have created an alternative to classic pedagogy most frequently represented in schools. One of the founders of a new school of teaching was Paulo Freire who basically thought that classic pedagogy was rather conservative and discriminatory; a more potent social dimension was introduced in his way of teaching, i.e. it was predominantly based on social criticism. In a way, this method of teaching represented a continuation of what Heathcote and Bolted had already created in England.

His conception of education also implies a new method in drama teaching, since its starting point represents the development of students' critical thinking. Having been himself a teacher in Brazil and simultaneously a witness of repressive state politics, Freire thought that one of the main pillars of the dominant (repressive) system was the system of education that basically ensured that the oppressed should not change their social position unless crucial internal (educational) changes were made. This is the reason his theory was perceived as rather dangerous and subversive by the Brazilian Government in the second half of the $20^{\text {th }}$ century. Freire himself was arrested, his theory got banned in 1964, but the insights of his pedagogy of the oppressed (or critical pedagogy) are very much important for the present moment. 
These are the most dominant characteristics of the „banking” system of education, according to Freire: a) the teacher teaches, students are taught; b) the teacher knows everything, students are ignorant; c) the teacher speaks, students obediently listen to the lecture; d) the teacher is in charge of discipline, students are disciplined; e) the teacher imposes his choices, students unquestionably accept them; f) the teacher acts, students have the illusion of acting through the teacher's work; g) the teacher chooses the contents of the subject, students willingly accept them without being consulted; h) the teacher's authority is more important than the knowledge he conveys which is in direct collision with students' freedom; i) the teacher is the subject of teaching whereas students represents its object (2005: 22).

This system of education mirrors the social system in which certain social groups are marginalized and adjusted to dubious social values. Hence, Freire believes that this kind of educational system represents the crux of oppressive behavior - the more students store the taught knowledge in a passive fashion, the less is their critical thinking applied in practice, which ultimately results in the passive outlook towards the society and the eventual change they could envision (2005: 22).

The method he suggests to be applied in the educational system is the socalled problem-posing education based on dialogue and communication between teachers and students that insists on constant questioning of both teachers' and students' views, which enables both parties to simultaneously teach and learn. In this relationship, no one is an authority, because the authority is on the side of truth, that is, universal ideas, so the eventual arguments based on the authority of participants in the dialogue are no longer valid. This process, claims Freire, is not „cognitive” from one point of view and ,narrative” from the other - it is cognitive in both ways, since its participants are equal (2005: 26).

In this method of teaching, students are constantly urged to answer various challenges, solve problems and influence the attitudes of others while changing their own views. This makes them less isolated and alienated in the teaching process and, at the same time, they are engaged in all the changes that take place their commitment and trust to take part in the teaching process represent a good preparation for their future social endeavors.

"Education as an expression of freedom - contrasted to education as an expression of dominance - denies the view that man is abstract, isolated, disconnected from and independent of the world; also, it denies the fact that the world exists as a reality distanced from people". (Freire 2005: 27) 
Whereas the banking system of education is based on the process of ascribing mythological features to the society as a distanced, inconceivable phenomenon, problem-posing education demythologizes the society and thus critically and creatively transforms it. Finally, Freire's pedagogy is ultimately humanistic since all individuals, notwithstanding their sex, race, education and gender, are given equal possibilities to think and judge critically, to be aware of incompleteness of their views and work on their future development. This can all be achieved through a constructive dialogue, based on mutual respect of individuals involved in it. The educational system should strive towards this practice, so that a similar practice could be used in daily life situations and future social and political conflicts.

Inspired by Freire's pedagogy, Augusto Boal wrote a book Theatre of the Oppressed (2008) in which he describes the teaching methods that are supposed to be practically applied in class. His ,theatre forum" (2008: 36) gives the spectator a possibility to become a part of the dramatic performance, change its ending, try diverse scenarios and later discuss them. It goes without saying that this dramatic method of teaching contributes to the development of students' critical thinking and avoidance of simplified resolutions to problems presented in the play. The greatest challenges for drama teachers thus represent the ability to make their students question and judge certain widespread views and thus nurture their capacities for critical thinking by demystifying and problematizing frequent contradictions in social relations.

The practical task we performed with the students in class concerned Shakespeare's play The Merchant of Venice. Our goal in choosing this play for arranging the theatre forum in class was for our students to expose, discuss and criticize the stereotype of the Jew in the Western civilization. What they perceived as the main problem in Shakespeare's play was a great dose of cruelty in treating a human being (though a Jew) by the Venetian Christians in the Renaissance period. Crucial Christian values, mercy, love and forgiveness, were not presented on the part of the Venetian Christians in the play; furthermore, their treatment of Shylock showed that they were rather declarative about these values, whereas in practice they did not express them. So, although Shakespeare's play was perceived as antiSemitic at the beginning of our discussion in class, the students' final conclusion was totally contrasted to their initial expectations. This conclusion made the students investigate the position of the Jews from the Renaissance period as the beginning of modernity to the present moment. A very fruitful discussion concerning the atrocities the Jews were exposed to particularly during the Second 
World War, the relevance of the Holocaust for the present moment, the issue of freedom to express diverse religious views in the modern society were only some of the topics raised after reading Shakespeare's play.

\subsection{Martha Nussbaum}

Following in the footsteps of Freire, Martha Nussbaum speaks about socially and politically engaged dramatic method of teaching. In Cultivating Humanity (1997), she insists on the idea that telling stories and the mere act of reading represent crucial activities for creating one's integrity. By referring to Aristotle who claimed that the main task of the poet was to portray not what actually happened but what might have happened, Nussbaum states that the mere awareness of diversity is a rather valuable means in the world of politics (1997: 248).

"The citizen of the world" (1997: 248) phrase is quite frequently used by Nussbaum. One can become a citizen of the world solely by passing through a humanist model of education - a kind of education whose main goal is to develop empathy. In spite of conspicuous trends in contemporary education in which humanist subjects are rather marginalized, even perceived as redundant since they are not focused on making profit, a great number of intellectuals tried to defend humanist disciplines. In The Death of Universities (2010), Terry Eagleton claims that proper education has to incorporate humanist subjects. If history, philosophy and other similar sciences disappear from the world of academia, the objects for technical training or corporate research institutes would remain. But it is also important to notice that these would not be proper universities and that it would be a misconception to ascribe them to academia. Tony Kushner in his article A Modest Proposal (1998) agrees with Eagleton and claims that the mere concept of education is contrasted to the act of training. Education as a concept in itself entails the capacities for the future creative and critical development of an individual. In the same vein, William Golding in his essay On the Crest of the Wave (1974) states that education today refers to the training of future technicians, soldiers and physical workers, and should not bear this dignified name anymore. It should be referred to as training, similar to the one conducted with dogs.

In Cultivating Humanity (1997), Nussbaum claims that it would be devastating if we became a nation of technically competent people who lost the ability to think critically, question themselves and respect social diversity (1997: 274). One of the aims of this essay represents the idea that by teaching literature (drama in particular) students can obtain proper humanistic education that would 
expose them to different cultures, customs, religions, nations and apart from the literary aspect, it could also provide them with insights into historical, philosophical and artistic movements and epochs. In other words, proper knowledge is not gained by the accumulation of scientific details, but by developing ,sympathetic imagination” (Nussbaum 1997: 247).

This kind of empathy for members of different cultures enables us to experience them ,not as dangerous aliens, but as people whose problems and abilities are pretty similar to ours" (Nussbaum 1997: 247). Since these peoples mostly possess different worldviews, it is sometimes rather difficult to identify or sympathize with them while reading a literary work, claims Susanne Keen (2006: 209). Nussbaum thus insists on the idea of including literary works that do not originate in the Western culture into teaching curricula since they could represent a challenge for students. Viewed from this perspective, literature is socially and even politically relevant. Controversial social issues are mostly present in the domain of drama. By posing a problem and leaving it to be resolved by students, teachers, audience, drama does not only satisfy our esthetic sense but also creates active social members. In that sense, teachers who open diverse discussion topics, demystify moral messages and encourage critical thinking have a great social responsibility.

A good example of what Nussbaum had on her mind when emphasizing the significance of multiculturalism was practically presented to the students through a discussion about Shakespeare's Othello, through a play that originated in Western culture. The issue of race that Shakespeare posed was again used in class to reveal the hypocrisy of the ,white" Venetians (just like in The Merchant of Venice). In other words, while warring and fighting on the side of the Venetians, Othello, the Moor was a good subject of the state, whereas the problem arises when the coloured warrior is to get married to the „white" daughter of the Venetian senator. His services after the marriage ceremony were no longer needed in Venice and as a castaway from the Christian state he was supposed to create a new identity as a lover and not a warrior anymore - a process that quite expectedly ended as a tragedy. Apart from the disrespect for the Other (nations), the students also judged a society which was merely based on material gain whereas genuine affection was not even considered as a possible option.

Literature is quite convenient for creating an interest in diverse characters because in real life we usually do not have insights into what people feel or think. In a literary work, characters' thoughts, feelings, dreams, experience is presented and internal private worlds are exposed. By the act of reading, we can develop 
techniques to glimpse into the internal sphere of the people around us and by cherishing sympathy, empathy and understanding, modern society can definitely be altered, claims Nussbaum:

"Narrative imagination is in different ways an important basis of moral interaction...that ultimately leads to respect for a private sphere no matter how different it was from a dominant social norm." (1997: 251)

The school curricula have to be based on the principle of multiculturalism, which is a basic principle of literature. Only in this way would literature be regarded as a social and not as an esthetic activity. Thus, every act of reading should include a social, humanist and even political context, because resisting this way of reading or ignoring the fact that it represents a social practice of a particular social group does again represent a political reading (Nussbaum 1997: 265). By asking questions, even the ones that seem to be controversial or hardly understandable to students, certain intriguing issues are introduced that can lead to the process of overcoming a stereotypical way of thinking and discovering new social and political views and outlooks. On the other hand, it is very important not to insert one's own views into literary works and character psychology. That is why both sympathetic and critical thinking should be cultivated (Nussbaum 1997: 260).

Opposed to the educational system based on making profit, Nussbaum creates the idea of a liberal ,inclusive model of citizenship" that would potentially generate men and women that will conscientiously take part in a democratic society (1997: 350). The mere concept of democracy is based on men capable of making their own decisions and judgments about a social and political system. Education without humanist subjects is unfortunately void of insights into different forms of social, political and historical orders, their benefits and consequences, as well as the ability for an individual to assess diverse social phenomena. This „banking” concept of education, as Freire calls it, is beneficial for the current ruling elite that cannot materially benefit from a thinking citizen and possible political dissident. Teaching drama (and literature in general) with its great potential (controversial topics, multiculturalism, issues of race, class, gender and, after all, justice and morality) has a great impact on creating the citizen of the world that can take part in a democratic society and definitely make a change in order for a more humane world to be created. 


\section{CONCLUSION}

After employing Heathcote's, Freire's and Nussbaum's practical techniques of dramatic method of teaching in class, an assessment survey was conducted. It was performed in the period 2016-2018 with the students who attended the course in English Renaissance literature (120 students of the English language and literature were involved in the anonymous survey; the survey concerned only the first year students since the English Renaissance literature course is obligatory in the second semester of studies at the English Department, Faculty of Philosophy in Niš, Serbia). These are the questions that were raised in the assessment sheet:

Do you find the dramatic method of teaching beneficial for your future education/personal development?

If yes - what elements of this method of teaching are particularly useful? If not - state the reasons.

We were rather delighted to discover that not a single person found the dramatic method of teaching useless and unnecessary for their future education and personal development. One of the most frequent reasons for finding the dramatic method of teaching useful concerned the fact that students were finally not regarded as passive recipients of given knowledge, but were perceived as equal participants in the complex process of learning. The constant dialogue among the students, as well as between them and the teachers made them feel more selfconfident, active and assertive in class. Apart from these findings, it is also very important to emphasize that some students also asserted that by participating in the applied theatre in class, they had the impression that their English was improving and getting more fluent.

The main aim of this anonymous survey was to obtain the students' feedback about the dramatic method of teaching practiced in the literature classes that could eventually offer valuable insights into their applicability at the university level. Once obtained, the results are presented in the concluding segment of this paper. Although the answers given by the students are rather satisfactory and show that we are on the right track of distributing knowledge and creating a strong sense of critical judgment among the students, we are quite aware of the limitations of this survey. Namely, it represents an initial stage in a complex research that would potentially involve a more studious approach to the practical aspects of the dramatic method of teaching. Our idea here is to present these initial findings and 
emphasize the validity of this teaching method. It is our plan to conduct a more detailed survey, involving more students, with a large number of issues that they could personally relate to and explain for the sake of enhancing the teaching process. Of course, this sort of research cannot be conducted in the pandemic circumstances, so we are looking forward to the return to regular classes and further verifiable inquiries of this method.

Although quite aware of the educational benefits of the dramatic method of teaching, it is our experience that this way of teaching is very challenging and demanding. As teachers, we were supposed to be the mediators between the artistic ideas and students' way of comprehending them. Our idea in choosing the dramatic texts to be analyzed in class was directed by the universality of their topics, i.e. we wanted to make the Renaissance texts closer to the modern way of thinking and experiencing the world. The enacting of different parts from the given plays, as well as vivid discussions that overcome their dramatic structure certainly testifies to the fact that we were on the right track. Finally, it is our experience that this method of teaching is rather difficult because one can never predict the direction in which the applied theatre in class would eventually lead you. In other words, teachers can never be fully prepared for what awaits them in class since diverse techniques of improvisation are crucial for the staging of the applied theatre. Nonetheless, it is our belief that this way of teaching rightly possesses the qualities of being educational and inspiring. It is also our belief that Heathcote, Freire and Nussbaum were right to assert that this was the only proper method of teaching drama. We might as well add - at the university level, for sure.

\section{REFERENCES}

Boal, A. (2008). Theatre of the Oppressed. London: Pluto Press.

Eagleton, T. (2010). The Death of Universities. The Guardian, 17 Dec. Accessed on January 20, 2018 from <https://www.theguardian.com/commentisfree/ 2010/dec/17/death-universities-malaise-tuition-fees>.

Freire, P. (2005). Pedagogy of the Oppressed. New York, London: Continuum.

Golding, W. (1974). On the Crest of the Wave, in The Hot Gates (London: Faber and Faber): 43-48.

Heathcoat, D. (2002). Contexts for Active learning: Four Models to Forge Links Between Schooling and Society. Accessed on July 15, 2018 from $<$ http://www.mantleoftheexpert.com/blog-post/dorothy-heathcote-fourmodels-for-teaching-learning/> 
Hornbrook, D. (1998). Education and Dramatic Art. London and New York: Routledge.

Keen, S. (2006). A Theory of Narrative Empathy. Narrative 14 (3): 207-236. Accessed on January 11, 2018 from <http://brainnarratives.qwriting.qc. cuny.edu/files/2012/12/keen- a_theory_of_narrative_empathy.pdf >

Kushner, T. (1998). A Modest Proposal. American Theatre 15 (1): 20-22, 77-89. Accessed on January 20, 2018 from <http://www.dennisbaker.net/docs/ modest_proposal.pdf >

Nussbaum, M. (1997). Cultivating Humanity: a Classical Defense of Reform in Liberal Education. Harvard: Harvard University Press.

Wagner, B. J. (1976). Dorothy Heathcote: Drama as a Learning Medium. Washington D.C.: National Education Association.

Милена Каличанин

Универзитет у Нишу

Филозофски факултет

Кристина Петровић

Универзитет у Нишу

Филозофски факултет

ПОДУЧАВАњЕ УЗ ПОМОЋ ДРАМЕ: ИЗАЗОВИ И ПРЕДНОСТИ

Резиме

Често се у академској литератури могу наћи подаци о ефикасности драмског метода подучавања и његовом значају за лични развој студената. Основни практични аспект ове методе наставе обухвата, пре свега, стицање разноврсних друштвених и језичких вештина што указује на њен огроман интердисциплинарни потенцијал. Поред предности, подучавање драме представља изузетно изазован наставнички задатак, јер наставници морају да посредују између света уметника и реципијената њихове уметности. Како би истакли изазове и предности подучавања драме, теоријски оквир рада почива на пионирском раду Дороти Хиткот $(1976,1998)$, као и на критичким увидима П. Фреиреа (2005) и М. Нусбаум (1997).

Дијалогичност, вежбе имагинације у замишљеним социјалним и етичким ситуацијама, промена перспективе чине само неке од елемената на којима је Дороти Хиткот радила са ученицима. Разлика у односу на стандардне драмске радионице је у томе што су биле засноване на импровизацији, без унапред припремљеног драмског предлошка. Ослањајући се на њене практичне увиде, Фреире ствара метод проблемске наставе. Заснован на дијалогу и комуникацији, овај метод омогућава међусобно и непрестано преиспитивање ставова наставника и ученика. У том процесу обе стране уче и истовремено подучавају. Марта Нусбаум сматра да се право образовање не постиже гомилањем знања, већ развијањем саосећајне имагинације. 
Припаднике других раса, класа, нација и религија одликују не само другачији животни избори, већ и другачији поглед на свет. Зато је тешко идентификовати се са њима или развити емпатију читајући књижевно дело. Стога је потребно, тврди М. Нусбаум, да се у школске програме укључе дела која не потичу из западне културе, те за ученике представљају изазов.

Методичке перспективе наведених теоретичара о драми као медијуму учења се у раду комбинују са резултатима интерног истраживања спроведеног у периоду од 2016. до 2018. године на Филозофском факултету у Нишу, приликом извођења курса из Енглеске ренесансне драме. Један од главних закључака овог интерног истраживања је да је драмски метод подучавања, иако изузетно захтеван, добио само позитивне рецензије студената.

Кључне речи: драмски метод подучавања, Хиткот, Фреире, Нусбаум, енглеска ренесансна драма.

Received: 7 April 2021

Accepted: 19 July 2021 